Corresponding Author:

P. A. Marino

pamarcast@uho.edu.cu

Received: 22 July 2018

Accepted: 9 September 2018

Published: 8 October 2018

Publishing services provided by Knowledge $\mathrm{E}$

(c) P. A. Marino et al. This article is distributed under the terms of the Creative Commons

Attribution License, which permits unrestricted use and redistribution provided that the original author and source are credited.

Selection and Peer-review under the responsibility of the Breakthrough Directions of Scientific Research at MEPhI Conference Committee.

\section{Obtaining and Structural Characterization of M-type Hexaferrites Doped with Two Cations in the $\mathrm{Fe}^{3+}$ Sites}

\section{P. A. Marino ${ }^{1}$, V. A. Lapshinsky $y^{2,3}$, C. Pupo 1,2, J. Matilla ${ }^{4}$, and A. Vega ${ }^{1}$}

${ }^{1}$ University of Holguin, campus 'Oscar Lucero Moya', XX anniversary avenue, Guardalavaca road, Piedra Blanca, Holguin, 80100, Cuba

${ }^{2}$ Peoples' Friendship University of Russia, 6 Miklukho-Maklaya street, Moscow, 117198, Russian Federation

${ }^{3}$ National Research Nuclear University MEPhl (Moscow Engineering Physics Institute), Kashirskoe shosse 31, 115409, Moscow, Russia

${ }^{4}$ University of Granma, Bayamo-Manzanillo road, 17.5 km, Bayamo, 85100, Cuba

\section{Abstract}

A study of the microstructural and structural properties of M-type barium hexaferrites (BaM) samples doped with two dopants in the $\mathrm{Fe}^{3+}$ sites: $\left(\mathrm{Co}^{3+}, \mathrm{Al}^{3+}\right),\left(\mathrm{Co}^{2+}, \mathrm{Ti}^{4+}\right)$ and $\left(\mathrm{CO}^{2+}, \mathrm{Sn}^{4+}\right)$ is reported. The samples were obtained using the conventional ceramic method. The structure was investigated by using of X-ray diffraction (XRD) to determine the dopant distribution in the $\mathrm{Fe}^{3+}$ sites.

\section{Introduction}

The BaM structure consists of five distinct Fe crystallographic sites, that is, three octahedral $\left(12 \mathrm{k}, 4 \mathrm{f}_{v i}\right.$ and $\left.2 \mathrm{a}\right)$ sites, one tetrahedral $\left(4 \mathrm{f}_{i v}\right)$ and one trigonal bipyramid (2b) site [1].

The understanding of the effect of different cations on the microstructural and magnetic properties of $M$-type barium hexaferrite is one of the most important tasks related with the use of these materials in technological applications [2]. Preparation of the ferrites has been investigated in a very intensive way [3], particularly the use of ferrites composites to synthesize materials with improved characteristics [2] and the synthesis from solutions, to meet the stringent requirements to the fineness and morphology of the particles of these materials: high homogeneity, optimal size and strong shape anisotropy [4].

In general, there are two ways to modify the properties of the M-type barium ferrite by using of dopants: The substitution in the $\mathrm{Ba}^{2+}$ crystallographic site and the substitution in the $\mathrm{Fe}^{3+}$ sites: 
As substitutes for $\mathrm{Ba}^{2+}$ can be used ions of metals with ionic radius larger than ionic radius of $\mathrm{Fe}^{3+}$, such as the rare earth elements: $\mathrm{La}, \mathrm{Sm}, \mathrm{Nd}, \operatorname{Pr}\left[5^{-7}\right]$, with the purpose to increase saturation magnetization $\left(M_{S}\right)$ and coercive field $\left(H_{C}\right)$, as well as to inhibit the growth mechanism of the material grains at high temperatures. In the $\mathrm{Fe}^{3+}$ sites, single substitutions have been carried out with only one dopant [8-10] and substitutions with different cationic combinations.

In the case of two dopants, a number of different combinations have been investigated, such as $\left(\mathrm{Co}^{2+}, \mathrm{Ti}^{4+}\right)[5,10,11],\left(\mathrm{Co}^{2+}, \mathrm{Sn}^{4+}\right)[3],\left(\mathrm{Ni}^{2+}, \mathrm{Zr}^{4+}\right)[12],\left(\mathrm{Zn}^{2+}, \mathrm{Zr}^{4+}\right)$ [13] and $\left(\mathrm{Zn}^{2+}, \mathrm{Ti}^{4+}\right)[14]$, among others. Substitution is carried out in dependence on the required material properties, according to its use, since the magnetic properties of BaM have a strong dependence on the substitution in the $\mathrm{Fe}^{3+}$ sites.

The objective of the present investigation is to study microstructural and structural properties of $\mathrm{M}$-type barium hexaferrite doped with $\left(\mathrm{CO}^{3+}, \mathrm{Al}^{3+}\right),\left(\mathrm{CO}^{2+}, \mathrm{Ti}^{4+}\right)$ and $\left(\mathrm{CO}^{2+}\right.$, $\mathrm{Sn}^{4+}$ ), obtained using the conventional ceramic method.

\section{Materials and Methods}

The samples were obtained by the traditional ceramic method, using $\mathrm{BaCO}_{3}, \mathrm{Fe}_{2} \mathrm{O}_{3}$, $\mathrm{Al}_{2} \mathrm{O}_{3}, \mathrm{TiO}_{2}, \mathrm{CoO}, \mathrm{CO}_{2} \mathrm{O}_{3}$ and $\mathrm{SnO}_{2}$ as starting materials. They were mixed in the required stoichiometric ratio according to the chemical formula $B a F e_{(12-2 x D j)} A_{x D j} B_{x D j} O_{19}$, where $\mathrm{A}_{x D j}=\mathrm{Al}^{3+}, \mathrm{Ti}^{4+}, \mathrm{Sn}^{4+}$ and $\mathrm{B}_{x D j}=\mathrm{Co}^{3+}, \mathrm{Co}^{2+}$ with dopant ion composition $\mathrm{xDj}$ $=0.0,0.1,0.2,0.5,0.7$, and 1.3.

The structural characterization was carried out from the $X$ rays diffraction patterns, and the wavelength of radiation was Co $\left[\lambda\left(k_{\alpha 1}\right)\right]=1.7889 \AA$.

The qualitative phase analysis was carried out by Hanawalt method and software Match Phase Identification from Powder Diffraction. Each diffraction pattern was refined by Rietveld method, using the Fullprof software.

The experimental density $\rho_{\text {exp }}$ of each sample was determined to measure their dimensions and mass. Their theoretical density $\rho_{\text {teo }}$ was determined considering its stoichiometry, using the expression:

$$
\rho_{\text {teo }}=2 \frac{M_{B a}+[12-2(x D j+y D p)] M_{F e}+x D j M_{A}+y D p M_{B}+19 M_{O}}{N_{A} V_{c u}},
$$

where $M_{B a}, M_{F e}, M_{A}, M_{B}$, and $M_{O}$ are molecular masses of $\mathrm{Ba}^{2+}, \mathrm{Fe}^{3+}$, first dopant $A$, second dopant $B$ and $O^{2-}$, respectively, $N_{A}=6.023 \times 10^{23}$ molecules $/ \mathrm{mol}$ is Avogadro's number, and $V_{c u}$ is the unit cell volume determined from XRD patterns. 
For determination of the apparent size of the grains $d$ it was assumed that they are cylinders that conserve the hexagonal cell symmetry, and the Scherrer method was used:

$$
d=\frac{0.91 \lambda}{b \cos \theta_{m}},
$$

where $\lambda$ is the wavelength of radiation, $b$ is FWHM for not overlapping reflections of the material and $\theta_{m}$ is the angle corresponding to the maximum intensity of selected reflection [15].

The theoretical density of a compound was calculated through the expression:

$$
\rho_{\text {teo }}=1.66 \frac{n z \cdot M}{V_{c u}},
$$

where $n$ is the minimum number of molecules per cell unit, $z$ is a variable corresponding to the number of molecules with mass $M$ in the asymmetric part of the unit cell and $\mathrm{V}_{c u}$ is the cell volume.

It is also important, since its influence in the extrinsic magnetic parameters, the calculation of the fraction of pores $\mathrm{F}_{\text {por }}$ :

$$
F_{\text {por }}=\left(1-\frac{\rho_{\text {exp }}}{\rho_{\text {teo }}}\right) \cdot 100 \% .
$$

\section{Results and Discussion}

In the figures $1(a),(b)$ and (c), the patterns of XRD for each system, refined by the Rietveld method are shown. In the concentration range $0.0 \leq \mathrm{xDj}<0.5$, per formula unit the samples are practically single phases, since they present the characteristic main reflections of BaM. Therefore, a compound isoestructural has been obtained, with BaM at different concentrations of the substitute ions, with a high crystalline structure, in accordance with the shape of each reflection and its low background level.

In general, in these figures, variations of the relative intensity are observed in comparison with the undoped sample. That indicates the occurrence of substitutions, as well as changes in the positions of the diffraction lines (they are increased with the quantity of dopant) until they imply remarkable cell unit distortions due to that the quantity of dopants increases two times.

With $x D j \geq 0.5\left(x D j_{c r i t}\right)$ for each dopant, the relative intensity in the respective patterns begins to have more evident variations as consequence of more changes in the atomic positions. The crystalline lattice begins to be distorted due to more important differences in the lattice parameters and, at the same time, the formation probability of other phases is increasing. 


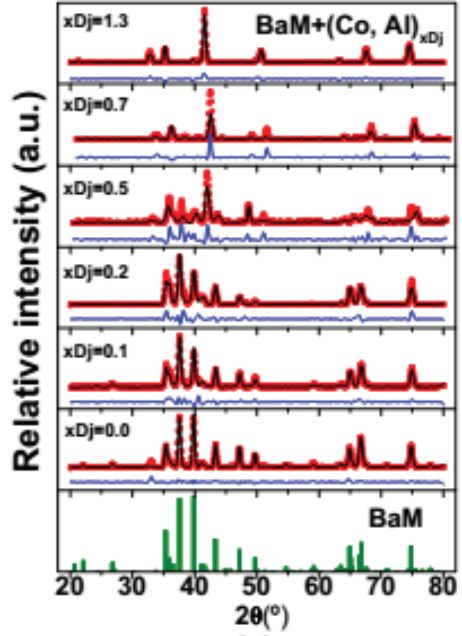

(a)

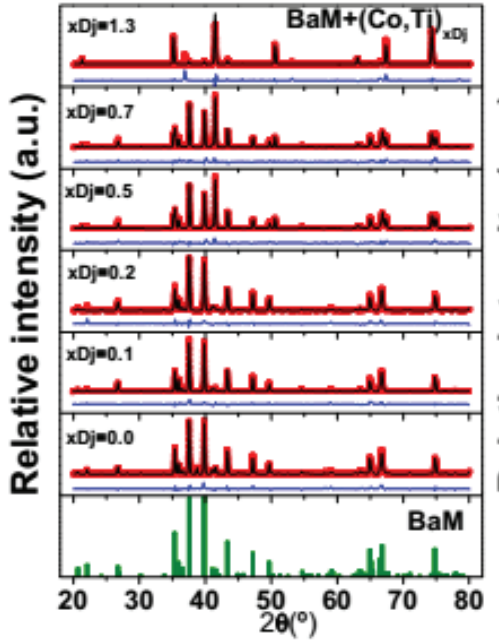

(b)

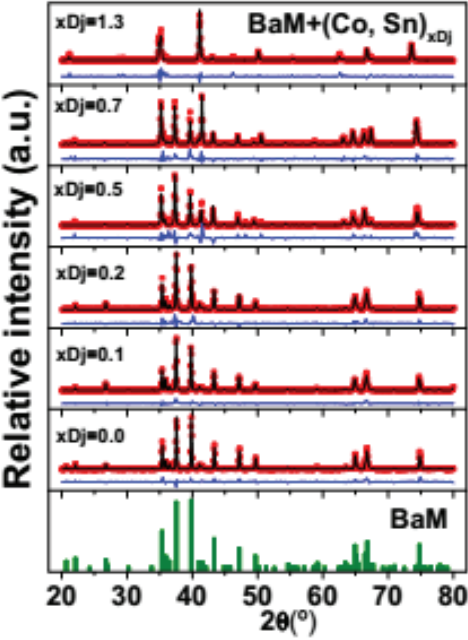

(c)

Figure 1: Refined $X$ rays diffraction patterns in function of $2 \theta$, using the concentration per formula unit as a parameter for the samples of the systems (a) BaM+(Co, Al $)_{x D_{j}}$ (b) BaM+(Co, Ti $)_{x D_{j}}$, and (c) BaM+(Co, $\mathrm{Sn})_{x D j}$.

In Table 1, the quality parameters of the XRD patterns refinement for the studied systems are shown.

TABLE 1: Quality parameters of the XRD patterns refinement for the studied systems: The R-pattern $\left(R_{p}\right)$, the R-weighted pattern $\left(R_{w p}\right)$, and the reduced chi-square $\left(X^{2}\right)$.

\begin{tabular}{|l|c|c|c|c|c|c|c|c|c|c|} 
xDj & \multicolumn{3}{c|}{ System $\mathrm{BaM}+(\mathrm{Co}, \mathrm{Al})_{x D j}$} & \multicolumn{3}{c|}{ System $\mathrm{BaM}+(\mathrm{Co}, \mathrm{Ti})_{x D j}$} & \multicolumn{3}{c|}{ System $\mathrm{BaM}+(\mathrm{Co}, \mathrm{Sn})_{x D j}$} \\
\hline & $\mathrm{R}_{p}$ & $\mathrm{R}_{w p}$ & $\mathrm{X}^{2}$ & $\mathrm{R}_{p}$ & $\mathrm{R}_{w p}$ & $\mathrm{X}^{2}$ & $\mathrm{R}_{p}$ & $\mathrm{R}_{w p}$ & $\mathrm{X}^{2}$ \\
\hline 0.0 & 12.2 & 19.3 & 14.2 & 19.7 & 24.7 & 10.1 & 11.0 & 14.0 & 3.06 \\
\hline 0.1 & 18.9 & 24.5 & 20.3 & 18.6 & 24.9 & 8.8 & 10.1 & 13.5 & 2.50 \\
\hline 0.2 & 18.9 & 24.6 & 25.3 & 17.1 & 22.9 & 9.0 & 12.3 & 16.9 & 4.79 \\
\hline 0.5 & 17.9 & 21.0 & 21.3 & 18.7 & 25.8 & 11.7 & 15.3 & 19.1 & 6.44 \\
\hline 0.7 & 21.3 & 20.7 & 11.1 & 18.0 & 24.2 & 10.1 & 12.2 & 15.6 & 4.64 \\
\hline 1.3 & 18.6 & 24.2 & 9.48 & 12.4 & 17.0 & 4.56 & 14.9 & 18.5 & 4.32
\end{tabular}

The results of the phase composition quantitative analysis for each sample are exposed in Table 2, where it is appreciated that an appropriate consistency exists between this analysis and the obtained XRD patterns.

In this table, the statements are quantitatively shown that were previously discussed qualitatively. The percent for each phase indicates that it is a logical consequence of the formation energy change for doped BaM, since the rest of obtained phases have a simpler structure.

In Table 3, the results of the structural characterization are shown.

In general, when these results are compared with the observed displacements in the XRD patterns, a slight sensibility of lattice parameters is noticed with $x D j \leq 0.2$. 
TABLE 2: Phase composition and fraction, in percent, of each phase for the studied systems.

\begin{tabular}{|c|c|c|c|c|c|c|}
\hline \multirow[t]{2}{*}{ xDj } & \multicolumn{2}{|c|}{ System BaM + (Co, Al $)_{x D j}$} & \multicolumn{2}{|c|}{ System BaM + (Co, Ti $)_{x D j}$} & \multicolumn{2}{|c|}{ System BaM + $(\mathrm{Co}, \mathrm{S} n)_{x D j}$} \\
\hline & Phases & $\%$ & Phases & $\%$ & Phases & $\%$ \\
\hline \multirow[t]{2}{*}{0.0} & $\mathrm{BaFe}_{12} \mathrm{O}_{19}$ & $99.6 \pm 0.5$ & $\mathrm{BaFe}_{12} \mathrm{O}_{19}$ & $93.1 \pm 0.7$ & $\mathrm{BaFe}_{12} \mathrm{O}_{19}$ & $100.0 \pm 0.8$ \\
\hline & & & $\mathrm{Fe}_{2} \mathrm{O}_{3}$ & $6.9 \pm 0.2$ & & \\
\hline 0.1 & $\mathrm{BaFe}_{11.8} \mathrm{CO}_{0.1} \mathrm{Al}_{0.1} \mathrm{O}_{19}$ & $99.6 \pm 0.7$ & $\mathrm{BaFe}_{11.8} \mathrm{Co}_{0.1} \mathrm{Ti}_{0.1} \mathrm{O}_{19}$ & $100.0 \pm 0.7$ & $\mathrm{BaFe}_{11.8} \mathrm{Co}_{0.1} \mathrm{Sn}_{0.1} \mathrm{O}_{19}$ & $100.0 \pm 0.8$ \\
\hline 0.2 & $\mathrm{BaFe}_{11.6} \mathrm{Co}_{0.2} \mathrm{Al}_{0.2} \mathrm{O}_{19}$ & $99.3 \pm 0.7$ & $\mathrm{BaFe}_{11.6} \mathrm{Co}_{0.2} \mathrm{Ti}_{0.2} \mathrm{O}_{19}$ & $100.0 \pm 0.6$ & $\mathrm{BaFe}_{11.6} \mathrm{Co}_{0.2} \mathrm{Sn}_{0.2} \mathrm{O}_{19}$ & $100 \pm 1$ \\
\hline \multirow[t]{3}{*}{0.5} & $\mathrm{BaFe}_{11.0} \mathrm{Co}_{0.5} \mathrm{Al}_{0.5} \mathrm{O}_{19}$ & $62.2 \pm 0.9$ & $\mathrm{BaFe}_{11.0} \mathrm{Co}_{0.5} \mathrm{Ti}_{0.5} \mathrm{O}_{19}$ & $69.6 \pm 0.6$ & $\mathrm{BaFe}_{11.0} \mathrm{Co}_{0.5} \mathrm{Sn}_{0.5} \mathrm{O}_{19}$ & $100 \pm 1$ \\
\hline & $\mathrm{AlCoFe}_{2} \mathrm{O}_{4}$ & $13.1 \pm 0.1$ & $\mathrm{CoFe}_{2} \mathrm{O}_{4}$ & $30.4 \pm 0.4$ & & \\
\hline & $\mathrm{FeO}$ & $24.8 \pm 0.9$ & & & & \\
\hline \multirow[t]{2}{*}{0.7} & $\mathrm{BaFe}_{10.6} \mathrm{Co}_{0.7} \mathrm{Al}_{0.7} \mathrm{O}_{19}$ & $56.3 \pm 0.1$ & $\mathrm{BaFe}_{10.6} \mathrm{Co}_{0.7} \mathrm{Ti}_{0.7} \mathrm{O}_{19}$ & $66.2 \pm 0.5$ & $\mathrm{BaFe}_{10.6} \mathrm{Co}_{0.7} \mathrm{Sn}_{0.7} \mathrm{O}_{19}$ & $55.0 \pm 0.8$ \\
\hline & $\mathrm{Fe}_{2} \mathrm{O}_{3}$ & $43.6 \pm 0.1$ & $\mathrm{CoFe}_{2} \mathrm{O}_{4}$ & $33.8 \pm 0.4$ & $\mathrm{Fe}_{3} \mathrm{O}_{4}$ & $45 \pm 1$ \\
\hline \multirow[t]{3}{*}{1.3} & $\mathrm{AlCoFe}_{2} \mathrm{O}_{4}$ & $90.2 \pm 0.1$ & $\mathrm{BaFe}_{9.4} \mathrm{Co}_{1.3} \mathrm{Ti}_{1.3} \mathrm{O}_{19}$ & $1.6 \pm 0.1$ & $\mathrm{BaFe}_{9.4} \mathrm{Co}_{1.3} \mathrm{Sn}_{1.3} \mathrm{O}_{19}$ & $1.1 \pm 0.1$ \\
\hline & $\mathrm{BaAl}_{2} \mathrm{O}_{4}$ & $8.8 \pm 0.4$ & $\mathrm{CoFe}_{2} \mathrm{O}_{4}$ & $98.4 \pm 0.9$ & $\mathrm{Fe}_{2.7} \mathrm{Sn}_{0.3} \mathrm{O}_{4}$ & $81 \pm 1$ \\
\hline & & & & & $\mathrm{CoFe}_{2} \mathrm{O}_{4}$ & $17.5 \pm 0.3$ \\
\hline
\end{tabular}

TABLE 3: Structural characterization parameters: Lattice parameters (a and $c$ ), ratio (c/a), cell unit volume $\left(V_{c u}\right)$, densities $\left(\rho_{\text {exp }}\right.$ and $\left.\rho_{\text {teo }}\right)$, average size of the crystallites $\left(\tau_{c r}\right)$, lattice strain coefficient $\left(\sigma_{t e n}\right)$ and fraction of pores $\left(F_{p o r}\right)$.

\begin{tabular}{|c|c|c|c|c|c|c|c|c|c|}
\hline ns & (Å) & & /a & & $\begin{array}{c}P_{\exp } \\
\left(\mathrm{g} / \mathrm{cm}^{3}\right)\end{array}$ & $\begin{array}{c}\rho_{\text {teo }} \\
\left(\mathrm{g} / \mathrm{cm}^{3}\right)\end{array}$ & & & $\mathrm{F}_{p o r}$ \\
\hline$(\mathrm{COAl})_{x D j}$ & & & 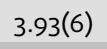 & & $4.57(.07)$ & $5.29(.01)$ & & & $0.136(2)$ \\
\hline $\mathrm{BaM}+(\mathrm{CoTi})_{x D j}$ & $5.892(2)$ & $23.2(2)$ & & $98 \pm 1$ & $4.57(.06)$ & $5.29(.01)$ & $122 \pm 8$ & & $136(2)$ \\
\hline $\mathrm{BaM}+(\operatorname{CoS} n)_{x D j}$ & $5.891(3)$ & $23.2(2)$ & 0 & $98 \pm 1$ & $4.57(.06)$ & $5.29(.01)$ & $134 \pm 1$ & & $0.136(2)$ \\
\hline $\mathrm{BaM}+(\mathrm{CoAl})_{x D j}$ & $5.886(5)$ & $23.2(4)$ & 94 & $696 \pm 2$ & $4.39(.02)$ & $5.28(.02)$ & $35 \pm 4$ & $294 \pm 6$ & $68(3$ \\
\hline $\mathrm{BaM}+(\mathrm{COTi})_{x D j}$ & $5.892(2)$ & $23.2(2)$ & 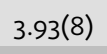 & $698 \pm 1$ & $4.24(.06)$ & $5.29(.01)$ & & $-8.2 \pm 0.2$ & $0.198(5$ \\
\hline $\mathrm{BaM}+(\operatorname{CoS} n)_{x D j}$ & $5.898(4)$ & $23.2(5)$ & $3.93(4)$ & $700 \pm 3$ & $3.93(.04)$ & $5.31(.02)$ & $293 \pm 7$ & $56.3 \pm 0.6$ & $.259(5$ \\
\hline $2 \mathrm{BaM}+(\mathrm{COAl})_{x D j}$ & $5.889(8)$ & $23.2(1)$ & 3.94(9) & $697 \pm 2$ & $4.25(.07)$ & $5.25(.02)$ & & & $0.190(3)$ \\
\hline $\mathrm{BaM}+(\mathrm{Co}$ & $5.892(1)$ & $23.2(2)$ & & $698 \pm 1$ & $4.14(.06)$ & $5.28(.02)$ & & & $0.216(4$ \\
\hline $\mathrm{BaM}+(\operatorname{CoS} n)_{x D j}$ & $5.895(7)$ & $23.2(4)$ & $3.93(6)$ & $699 \pm 2$ & $3.84(.07)$ & $5.35(.02)$ & $1349 \pm 148$ & $73.8 \pm 0.6$ & $0.282(5)$ \\
\hline $5 \mathrm{BaM}+(\mathrm{CoAl})_{x D j}$ & $5.841(1)$ & $22.8(7)$ & $3.90(3)$ & $676 \pm 2$ & $4.13(.08)$ & $5.33(.02)$ & & & $0.225(4)$ \\
\hline $\mathrm{BaM}+(\mathrm{CoTi})_{x D j}$ & & & & & $3.94(.07)$ & $5.29(.01)$ & & & $0.255(4)$ \\
\hline & $5 \cdot 917(3)$ & 23.3(5) & $3.93(8)$ & $708 \pm 3$ & $3.75(.01)$ & $5.37(.01)$ & & & $0.302(6)$ \\
\hline & $5.753(5)$ & $22.7(1)$ & $3.94(6)$ & $651 \pm 1$ & $4.10(.08)$ & $5.48(.01)$ & & $814 \pm 7$ & $0.251(4)$ \\
\hline & $5.887(3)$ & $23.2(9)$ & $3.94(1)$ & $696 \pm 1$ & $3.88(.04)$ & $5.29(.02)$ & & & $0.267(4)$ \\
\hline $\mathrm{BaM}+(\operatorname{CoS} n)_{x D j}$ & $5.917(7)$ & $23.4(1)$ & $3.95(5)$ & $709 \pm 2$ & $3.68(.04)$ & $5.42(.01)$ & $34 \pm 1$ & $298 \pm 5$ & $0.322(6)$ \\
\hline
\end{tabular}

With $x D j \geq 0.5$, besides the aforementioned causes, there is a phase overlapping influence and a variation of the intrinsic parameters, which increases the cell unit strain.

All that was previously stated is more evident for the system BaM + $(\mathrm{Co}, \mathrm{Al})_{x D j}$ because there is a greater difference between atomic number and ionic radius of the aluminum in comparison with these characteristics for the iron. 
In Table 4, the maximum quantity of dopant per site for each studied system is reported.

The quantity of cobalt in each site only differs in the system doped with $\left(\mathrm{Co}^{3+}, \mathrm{Al}^{3+}\right)$ in comparison with the other two systems, due to the difference between the ionic radius of $\mathrm{Co}^{3+}$ and $\mathrm{Co}^{2+}$. In both cases, the preferential sites are $12 \mathrm{k}, 4 \mathrm{f}_{v i}$ and $4 \mathrm{f}_{i v}$ although in this system a double quantity of cobalt goes to the site $12 k$, since the number of possible positions in this crystallographic site.

TABLE 4: The maximum quantity of dopant per site for each studied system.

\begin{tabular}{|c|c|c|c|c|c|c|c|c|c|c|c|}
\hline \multirow[b]{2}{*}{ xDj } & \multirow[b]{2}{*}{ Systems } & \multicolumn{5}{|c|}{ Distribution of Co per $\mathrm{Fe}^{3+}$ site } & \multicolumn{5}{|c|}{ Distribution of dopant Dj per $\mathrm{Fe}^{3+}$ site } \\
\hline & & $2 a$ & $2 b$ & $4 \mathrm{f}_{i v}$ & $4 \mathrm{f}_{v i}$ & $12 \mathrm{k}$ & $2 a$ & $2 b$ & $4 \mathrm{f}_{i v}$ & $4 \mathrm{f}_{v i}$ & $12 \mathrm{k}$ \\
\hline \multirow[t]{3}{*}{0.1} & $\mathrm{BaM}+(\mathrm{CoAl})_{x D j}$ & 0.002 & 0.002 & 0.004 & 0.009 & 0.083 & 0.002 & 0.001 & 0.002 & 0.010 & 0.085 \\
\hline & $\mathrm{BaM}+(\mathrm{CoTi})_{x D j}$ & 0.002 & 0.002 & 0.003 & 0.009 & 0.083 & 0.002 & 0.001 & 0.003 & 0.009 & 0.084 \\
\hline & $\mathrm{BaM}+(\operatorname{CoS} n)_{x D j}$ & 0.002 & 0.002 & 0.003 & 0.009 & 0.083 & 0.003 & 0.000 & 0.000 & 0.010 & 0.087 \\
\hline \multirow[t]{3}{*}{0.2} & $\mathrm{BaM}+(\mathrm{CoAl})_{x D j}$ & 0.005 & 0.003 & 0.007 & 0.019 & 0.165 & 0.005 & 0.002 & 0.003 & 0.019 & 0.171 \\
\hline & $\mathrm{BaM}+(\mathrm{CoTi})_{x D j}$ & 0.005 & 0.003 & 0.007 & 0.019 & 0.166 & 0.005 & 0.003 & 0.006 & 0.019 & 0.167 \\
\hline & $\mathrm{BaM}+(\operatorname{CoS} n)_{x D j}$ & 0.005 & 0.003 & 0.007 & 0.019 & 0.166 & 0.005 & 0.001 & 0.001 & 0.021 & 0.172 \\
\hline \multirow[t]{3}{*}{0.5} & $\mathrm{BaM}+(\mathrm{CoAl})_{x D j}$ & 0.013 & 0.009 & 0.020 & 0.050 & 0.408 & 0.013 & 0.006 & 0.008 & 0.050 & 0.424 \\
\hline & $\mathrm{BaM}+(\mathrm{CoTi})_{x D_{j}}$ & 0.013 & 0.009 & 0.019 & 0.051 & 0.409 & 0.013 & 0.008 & 0.017 & 0.050 & 0.412 \\
\hline & $\mathrm{BaM}+(\operatorname{CoS} n)_{x D j}$ & 0.013 & 0.009 & 0.019 & 0.051 & 0.409 & 0.015 & 0.003 & 0.002 & 0.058 & 0.422 \\
\hline \multirow[t]{3}{*}{0.7} & $\mathrm{BaM}+(\mathrm{CoAl})_{x D j}$ & 0.019 & 0.013 & 0.030 & 0.073 & 0.566 & 0.018 & 0.008 & 0.012 & 0.070 & 0.591 \\
\hline & $\mathrm{BaM}+(\mathrm{CoTi})_{x D j}$ & 0.018 & 0.013 & 0.029 & 0.073 & 0.566 & 0.019 & 0.012 & 0.025 & 0.072 & 0.573 \\
\hline & $\mathrm{BaM}+(\operatorname{CoS} n)_{x D j}$ & 0.019 & 0.013 & 0.029 & 0.073 & 0.566 & 0.023 & 0.005 & 0.003 & 0.087 & 0.582 \\
\hline
\end{tabular}

For $\mathrm{Al}^{3+}$ in the system $\left(\mathrm{CO}^{3+}, \mathrm{Al}^{3+}\right), \mathrm{Ti}^{4+}$ in the system $\left(\mathrm{CO}^{2+}, \mathrm{Ti}^{4+}\right)$ and $\mathrm{Sn}^{4+}$ in the system $\left(\mathrm{Co}^{2+}, \mathrm{Sn}^{4+}\right)$, the preferential sites are $12 \mathrm{k}, 4 \mathrm{fvi}$ and, in smaller proportion, the site 2 a, because the radius of these sites is bigger than the radius of the two other sites. In absolute terms, the sum of the quantity of dopants in the site 4 fvi in the system $\left(\mathrm{Co}^{2+}, \mathrm{Sn}^{4+}\right)$ is always rather bigger.

\section{Conclusions}

A study of the microstructural and structural properties of the M-type doped Barium hexaferrite according to the stoichiometric formulation $B a F e_{(12-2 x D j)} A_{x D j} B_{x D j} O_{19}$, where $\mathrm{A}_{x D j}=\mathrm{Al}^{3+}, \mathrm{Ti}^{4+}, \mathrm{Sn}^{4+}$ and $\mathrm{B}_{x D j}=\mathrm{Co}^{3+}, \mathrm{Co}^{2+}$ with dopant ion composition $\mathrm{xDj}$ $=0.0,0.1,0.2,0.5,0.7$, and 1.3 has been reported. The XRD analysis show a variation of the host lattice parameters. When doping these systems, there is a value $\mathrm{XDj}_{\text {crit }}=$ 0.5 , starting from which the structural characterization shows that the characteristic 
reflections of BaM begin to disappear. Furthermore, the value $\mathrm{xDj}_{\text {crit }}$ varies with the type and the quantity of dopants per formula unit.

\section{References}

[1] Mariño-Castellanos, P. A., Moreno-Borges, A. C., Orozco-Melgar, G., et al. (2011). Structural and magnetic study of the Ti4+-doped barium hexaferrite ceramic samples: Theoretical and experimental results. Physica B: Condensed Matter, vol. 406, pp. 3130-3136.

[2] Pullar, R. C. (2012). Hexagonal Ferrites: A Review of the Synthesis, Properties and Applications of Hexaferrite Ceramics. Progress in Moterials Science, vol. 57, pp. 11911334.

[3] Gao, X., Du, Y., Liu, X., et al. (2011). Materials Research Bulletin, vol. 46, pp. 643-648.

[4] Pullar, R. C., Bdikin, I. K., and Bhattacharya, A. K. (2012). Magnetic properties of randomly oriented BaM, SrM, Co2Y, Co2Z and Co2W hexagonal ferrite fibres. Journal of the European Ceramic Society, vol. 32, pp. 905-913.

[5] An, S. Y., Shim, I. B., and Kim, C. S. (2002). MÃ CoâTi substituted barium hexaferrite nanoparticles. Journal of Applied Physics, vol. 91, pp. $8465-8467$.

[6] Li, W., Qiao, X., Li, M., et al. (2013). La and Co substituted M-type barium ferrites processed by sol-gel combustion synthesis. Materials Research Bulletin, vol. 48, pp. 4449-4453.

[7] Zhang, Z., Liu, X., Wang, X., et al. (2012). Journal of Alloys and Compounds, vol. 525, pp. 114-119.

[8] Mariño-Castellanos, P. A., Somarriba-Jarque, J. C., and Anglada-Rivera, J. (2005). Magnetic and microstructural properties of the BaFe(12- (4/3)x)Snx019 ceramic system. Physica B: Condensed Matter, vol. 362, pp. 95-102.

[9] Mariño-Castellanos P A, Anglada-Rivera J, Cruz-Fuentes A and Lora-Serrano R 2004 J. Magn. and Magn. Mat. 280 214-220.

[10] Zhang, W., Bai, Y., Han, X., et al. (2013). Journal of Alloys and Compounds, vol. 546, pp. $234-238$.

[11] Bottoni, G. (2010). Journal of Magnetism and Magnetic Materials, vol. 322, pp. 16171619.

[12] Kanagesan, S., Jesurani, S., Velmurugan, R., et al. (2012). Structural and magnetic properties of conventional and microwave treated $\mathrm{Ni}$-Zr doped barium strontium hexaferrite. Materials Research Bulletin, vol. 47, pp. 188-192. 
[13] Wei, F. L., Fang, H. C., Ong, C. K., et al. (2000). Journal of Applied Physics, vol. 87, pp. 8636-8639.

[14] Soman, V. V., Nanoti, V. M., and Kulkarni, D. K. (2014). Effect of Substitution of Zn-Ti on Magnetic and Dielectric Properties of BaFe12019. Physics Procedia, vol. 54, pp. 30-37.

[15] Suryanarayana, C. (2001). Progress in Materials Science, vol. 46, pp. 1-184. 